\title{
TOXICITY AND PHYSIOLOGICAL EFFECTS OF SOME PLANT EXTRACTS ON FRUIT FLY INFESTING ASH GOURD
}

\author{
M.R. Amin ${ }^{1 *}$, S.M.A. Shafiullah ${ }^{1}$, E. Mondal ${ }^{1}$ and T. Ahmed ${ }^{2}$ \\ ${ }^{1}$ Department of Entomology, Bangabandhu Sheikh Mujibur Rahman Agricultural University \\ Gazipur, Bangladesh \\ ${ }^{2}$ Department of Agroforestry and Environment, Bangabandhu Sheikh Mujibur Rahman Agricultural \\ University, Gazipur, Bangladesh
}

\begin{abstract}
The aqueous extracts of neem Azadirachta indica, eucalyptus Eucalyptus globulus, telakucha Coccinia indica, mahogany Swietenia macrophylla and joba Hibiscus rosa-sinensis leaves were used to evaluate their toxicity and physiological effects on fruit fly Bactrocera cucurbitae (Diptera: Tephritidae) reared on ash gourd Benincasa hispida. The investigations were done with 1,2 and $4 \%$ extracts and an untreated control. The toxicity of the extracts varied with plant species, concentration and exposure period. Among the treatments, neem revealed the most toxic effect as it showed the lowest $\mathrm{LC}_{50}$ and $\mathrm{LC}_{95}$ values as well as steepest slope of the concentration curve. The order of toxicity of the plants was neem> eucalyptus $>$ telakucha> mehagony> joba. All the extracts reduced pupation, adult emergence, protein content in larval body and body weight of male and female flies. The highest reduction of protein, body weight of male and female flies, pupation and adult emergence were found with $4 \%$ neem extract. Among the tested extracts, $4 \%$ neem extract was found as the most effective botanical insecticide against $B$. Cucurbitae
\end{abstract}

Keywords: Botanical insecticides, Bactrocera cucurbitae, mortality, growth, development

\section{INTRODUCTION}

Ash gourd Benincasa hispida L. is one of the important cucurbitaceous vegetables in Bangladesh and other south-east Asian countries. This vegetable is mostly infested with fruit fly, epilachna beetle and red pumpkin beetle. Among these pests, fruit fly Bactrocera cucurbitae Coquillett (Diptera: Tephritidae) is the most destructive which causes damage to all the cucurbitaceous vegetables and its infestation level ranges from 20 to $100 \%$ depending on the cucurbitaceous species, climatic region and

\footnotetext{
* Corresponding author e-mail: mramin.bsmrau@gmail.com
} 
cultivation season (Atwal and Dhaliwal, 2000; Ramadan and Messing, 2003; Mannan, 2004; Sapkota et al., 2010). In Bangladesh, B. Cucurbitae caused 71.5\% and $21.0 \%$ fruit infestation on sweet gourd and ridge gourd, respectively (Amin et al., 2011).

The female fruit flies lay eggs inside the young, green and tender fruits or corolla of the flowers or stems by inserting their ovipositor. The maggots feed on the flowers, stems and mostly inside the developing fruits. The fruits attacked in early stages fail to develop properly, and drop or rot on the plant. Rabindranath and Pillai (1986) reported that the fruit fly infestations deteriorate fruit quality and yield of ash gourd. Due to internal feeding behavior of larvae, management of fruit fly is difficult. Bagging of fruits in scaffold is a suitable method in suppressing fruit fly infestation but this method is laborious and expensive (Mukherjee et al., 2007; Amin et al., 2008).

The farmers of Bangladesh are mostly relied on synthetic insecticides to combat this manacle pest. The synthetic insecticides not only kill the pest, but also direct killer of insect pollinators and natural enemies and create resistance to pest (Azad et al., 2011). Their excessive and inadvertent use in food crops and vegetables are disastrous to environment and human health (Kim et al., 2003; Desneux et al., 2007).

Now-a-days, environmentally safe products such as plant extracts, oils, and dusts are being incorporated in integrated pest management program for depletion of the use of chemical insecticides (Yuya et al., 2009). Many researchers in different countries have focused on the use of plant materials and extracts as insecticides against various insect pests (Moulton et al., 2002; Osoria et al., 2008).

The neem based insecticides containing azadirachtin have toxicity, repellence, feeding and oviposition deterrence, insect growth regulator activity, and have been reported to control more than 400 species of insects (Pineda et al., 2009). The active ingredients in neem have the ability to function at hormonal concentrations and produce ecdysone-type effects in susceptible insects (Govindachari et al., 2004). Ulrichs et al. (2008) reported that the third instar larvae of Spodoptera litura fed on castor leaves treated with salt grass Porteresia coarctata (Roxb.) leaf extract at different concentrations showed significant reduction in protein and DNA content in the fat body and midgut tissues.

Bangladesh possesses a lot of botanical species which have medicinal and insecticidal properties. That is why the botanicals are chief and these are promising sources of pest control materials. The botanical compounds azadirachtin, pyrethrum, nicotine and rotenone are recognized as effective insect-control agents (Isman, 1997). Therefore, in this study the locally available plants namely neem Azadirachta indica, eucalyptus Eucalyptus globules, joba Hibiscus rosa-sinensis, telakucha Coccinia indica and mahogany Swietenia macrophylla leaf extracts were evaluated against the mortality of fruit fly B. cucurbitae larvae reared on ash gourd fruit. The study also estimated the pupation and adult emergence rate, protein content in the adult flies and their body weight. 


\section{MATERIALS AND METHODS}

\section{Study site and condition}

The study was conducted in the laboratory of the Department of Entomology, Bangabandhu Shaikh Mujibur Rahman Agricultural University (BSMRAU), Gazipur, Bangladesh during November 2015 to June 2016. The insects were maintained in the laboratory at $12: 12 \mathrm{LD}, 28 \pm 2^{\circ} \mathrm{C}$ and $75 \pm 5 \% \mathrm{RH}$ providing ash gourd which was cultivated in the experimental field of BSMRAU.

\section{Preparation of extracts}

Leaves of neem Azadirachta indica, eucalyptus Eucalyptus globulus, joba Hibiscus rosa-sinensis, telakucha Coccinia indica and mahogany Swietenia macrophylla were collected from the BSMRAU campus and transported to the entomology laboratory. The collected leaves were washed with tap water and air dried for 7 days in the shade. Furthermore, the leaves were dried in an oven at $50-60^{\circ} \mathrm{C}$ for $24 \mathrm{~h}$ to obtain constant weight. The leaves were powdered mechanically by using an electric blender and passed through 40 mesh screen. The powder of each plant species were separately extracted in water. For each preparation, $10 \mathrm{~g}$ powder was macerated in a $2.5 \mathrm{~L}$ capacity glass bottle using $1 \mathrm{~L}$ water. Then the sample was shaken for $72 \mathrm{~h}$ using an electric shaker. The extract was filtered and the filtrate was considered $1 \%$ concentration $\left(1 \mathrm{~g} 100 \mathrm{ml}^{-1}\right)$. Similarly, 2 and $4 \%$ extracts were prepared and stored in a refrigerator at $4^{\circ} \mathrm{C}$ until insect bioassay.

\section{Mortality test}

Fresh ash gourd fruits were collected from the field and these were cut into pieces and therefore, treated with the extracts. The fruit pieces were then transferred into 9 $\mathrm{cm}$ diameter Petri dishes that contained maggots (first and second instar larvae). Each Petri dish had 10 maggots and fruit pieces were used as their diet. An untreated control observation was done with fresh fruit. Number of insect mortality in each Petri dish was recorded at 24, 48 and $72 \mathrm{~h}$ after treatment and percent mortality was calculated. The observed mortality was corrected following the formula of SchneiderOrellis (1949).

\section{Observation of pupation and adult insect emergence}

The $4 \%$ extracts of each plant was poured distinctly into the glass containers which had ash gourd pieces. The extracts were mixed with the fruit pieces and the pieces were placed in different Petri dishes and five pairs of newly emerged maggots were released in each Petri dish. The Petri dishes along with the maggots and ash gourd pieces were kept in the laboratory. A control observation was made with maggots and fresh ash gourd pieces. The Petri dishes were kept in net proof cages providing sands on the bottom for pupation of the larvae. Daily observation was made to know the rate of pupation and adult emergence. 


\section{Estimation of protein and body weight}

For determination of protein, 6 third instar larvae (One larva from each extract treated and untreated fruits) were selected and oven dried at $60^{\circ} \mathrm{C}$ and then powdered. Protein was determined by conventional Kjeldahl method following the protocol of Amin et al. (2011) and the percent reduction of protein in the treatments was calculated. In total 60 adult insects (five male and five female from each extract treated and untreated fruits) were used to determine their body weight. The weight was determined using a digital balance (AG 204, Mettler Toledo, Switzerland) and percent body weight reduction of the insects in different treatments were calculated.

\section{Statistical analysis}

Probit and Chi statistics were employed to analyze the toxicity and protein reduction, respectively. Pupation, adult emergence and body weight reduction data were analyzed by one way analysis of variance (ANOVA) and the mean differences were evaluated using Tukey's HSD posthoc statistics. All the analyses were performed using IBM SPSS 19.

\section{RESULTS}

The plant extracts at $24 \mathrm{~h}$ after treatment showed toxicity effect on the maggots of $B$. cucurbitae and the calculated $\mathrm{LC}_{50}$ and $\mathrm{LC}_{95}$ values ranged from 9.3 (6.0-63.7) to $13.9(9.2-40.2)$ and $18.7(11.1-150.5)$ to $37.2(20.2-101.4) \mathrm{g} / 100 \mathrm{ml}$, respectively (Table 1). Toxicity results differed significantly among the extracts and neem extract was found as the most effective one. Its concentration response curve showed the steepest slope which indicated that small variations in the concentrations induced greater responses in mortality. The order of mortality activity of the different plant extracts at $24 \mathrm{~h}$ post treatment showed neem $>$ eucalyptus $>$ telakucha $>$ mahogany $>$ joba.

Table 1. Toxicity effect of different plant extracts on the larvae of Bactrocera cucurbitae exposed to $24 \mathrm{~h}$ post treatment

\begin{tabular}{l|c|l|l|l|l|l|l}
\hline Plant & Slope $( \pm$ S.E) & $\mathrm{LC}^{\mathrm{a}} 50(95 \% \mathrm{fl})$ & $\mathrm{TR}_{50}$ & $\mathrm{LC}^{\mathrm{a}}(95 \% \mathrm{fl})$ & $\mathrm{TR}_{95}$ & $\chi^{2}(\mathrm{df})$ & $\mathrm{P}$ \\
\hline Neem & $0.17 \pm 0.03$ & $9.3(6.0-63.7)$ & 1.49 & $18.7(11.1-150.5)$ & 1.75 & $58.6(13)<0.001$ \\
Eucalyptus & $0.17 \pm 0.03$ & $9.4(5.9-198.2)$ & 1.48 & $19.0(10.9-473.6)$ & 1.72 & $66.3(13)<0.001$ \\
Telakucha & $0.13 \pm 0.03$ & $10.0(6.4-59.3)$ & 1.39 & $23.2(13.5-158.1)$ & 1.41 & $34.9(13)<0.01$ \\
Mahogany & $0.13 \pm 0.03$ & $11.6(7.1-201.2)$ & 1.20 & $23.9(13.4-471.8)$ & 1.37 & $38.6(13)<0.001$ \\
Joba & $0.09 \pm 0.03$ & $13.9(9.2-40.2)$ & - & $32.7(20.2-101.4)$ & - & $22.1(13)<0.05$ \\
\hline
\end{tabular}

Each datum represents the mean of five replicates, each set up with 10 adults $(\mathrm{n}=50)$. Concentrations are expressed as $\mathrm{g} \mathrm{ml}^{-1} \mathrm{fl}$ stands for fiducial limits. ${ }^{\mathrm{a}}$ Different concentrations $\left(1,2\right.$ and $\left.4 \mathrm{~g} 100 \mathrm{ml}^{-1}\right)$. 
The toxicity of the plant extracts at $48 \mathrm{~h}$ after treatment showed $\mathrm{LC}_{50}$ and $\mathrm{LC}_{95}$ values from $8.4(5.5-51.5)$ to $17.7(10.6-113.9)$ and $20.0(12.5-72.2)$ to $39.9(22.5-276.1) \mathrm{g}$ $100 \mathrm{ml}^{-1}$, respectively (Table 2). The neem extract revealed the lowest $\mathrm{LC}_{50}$ and the telakucha extract showed the lowest $\mathrm{LC}_{95}$ values which were statistically similar to eucalyptus. The concentration response curve of the telakucha and eucalyptus extracts showed identical having the steepest slope. The order of toxicity of the plant extracts at $48 \mathrm{~h}$ post treatment was neem> eucalyptus > telakucha > mahogany > joba.

Table 2. Toxicity effect of different plant extracts on the larvae of Bactrocera cucurbitae exposed to $48 \mathrm{~h}$ post treatment

\begin{tabular}{l|c|l|l|l|l|l|l}
\hline Plant & Slope $( \pm$ S.E) & LC $^{\mathrm{a}} 5(95 \% \mathrm{fl})$ & $\mathrm{TR}_{50}$ & $\mathrm{LC}^{\mathrm{a}}(95 \% \mathrm{fl})$ & $\mathrm{TR}_{95}$ & $\chi^{2}(\mathrm{df})$ & $\mathrm{P}$ \\
\hline Neem & $0.13 \pm 0.03$ & $8.4(5.5-51.5)$ & 2.11 & $20.7(12.2-152.9)$ & 1.93 & $45.3(13)$ & $<0.001$ \\
Eucalyptus & $0.14 \pm 0.03$ & $8.7(5.8-38.9)$ & 2.03 & $20.0(12.0-105.2)$ & 2.0 & $44.9(13)$ & $<0.001$ \\
Telakucha & $0.14 \pm 0.03$ & $8.7(5.9-27.3)$ & 2.03 & $20.0(12.5-72.2)$ & 2.0 & $36.6(13)$ & $<0.001$ \\
Mahogany & $0.10 \pm 0.03$ & $12.3(7.6-113.3)$ & 1.44 & $28.8(16.2-296.6)$ & 1.39 & $24.3(13)$ & $<0.05$ \\
Joba & $0.07 \pm 0.03$ & $17.7(10.6-113.9)$ & - & $39.9(22.5-276.1)$ & - & $11.3(13)$ & 0.58 \\
\hline
\end{tabular}

Each datum represents the mean of five replicates, each set up with 10 adults $(n=50)$. Concentrations are expressed as $\mathrm{g} \mathrm{ml}^{-1} \mathrm{fl}$ stands for fiducial limits. ${ }^{a}$ Different concentrations $\left(1,2\right.$ and $\left.4 \mathrm{~g}^{100 \mathrm{ml}^{-1}}\right)$.

The toxicity effects of different plant extracts at $72 \mathrm{~h}$ after treatment revealed $\mathrm{LC}_{50}$ and $\mathrm{LC}_{95}$ values from 6.1 (4.9-9.3) to 10.7 (7.7-21.5) and 13.5 (10.0-22.8) to 26.7 (17.9-57.9) g/100 ml, respectively (Table 3). Among the treatments, neem revealed the most toxic effect as it showed the lowest $\mathrm{LC}_{50}$ and $\mathrm{LC}_{95}$ values having the steepest slope of the concentration curve. The order of toxicity of the plants was neem $>$ eucalyptus > telakucha $>$ joba $>$ mahogany.

Table 3. Toxicity effect of different plant extracts on the larvae of Bactrocera cucurbitae exposed to $72 \mathrm{~h}$ post treatment

\begin{tabular}{l|c|l|l|l|l|l|l}
\hline Plant & Slope $( \pm$ S.E $)$ & LC $^{\mathrm{a}} 0(95 \% \mathrm{fl})$ & $\mathrm{TR}_{50}$ & $\mathrm{LC}^{\mathrm{a}}(95 \% \mathrm{fl})$ & $\mathrm{TR}_{95}$ & $\chi^{2}(\mathrm{df})$ & $\mathrm{P}$ \\
\hline Neem & $0.22 \pm 0.03$ & $6.1(4.9-9.3)$ & 1.75 & $13.5(10.0-22.8)$ & 1.98 & $33.5(13)$ & $<0.001$ \\
Eucalyptus & $0.13 \pm 0.03$ & $7.6(5.0-51.1)$ & 1.41 & $20.6(11.9-192.5)$ & 1.30 & $46.8(13)$ & $<0.001$ \\
Telakucha & $0.16 \pm 0.03$ & $7.8(5.4-27.6)$ & 1.37 & $17.8(11.0-74.2)$ & 1.5 & $52.0(13)$ & $<0.001$ \\
Mahogany & $0.10 \pm 0.03$ & $10.7(7.7-21.5)$ & - & $26.7(17.9-57.9)$ & - & $20.2(13)$ & 0.09 \\
Jaba & $0.11 \pm 0.03$ & $10.1(6.3-145.8)$ & 1.06 & $25.7(14.3-435.9)$ & 1.04 & $32.8(13)$ & $<0.01$ \\
\hline
\end{tabular}

Each datum represents the mean of five replicates, each set up with 10 adults $(n=50)$. Concentrations are expressed as $\mathrm{g} \mathrm{ml}^{-1} \mathrm{fl}$ stands for fiducial limits. ${ }^{\mathrm{a}}$ Different concentrations $\left(1,2\right.$ and $\left.4 \mathrm{~g} 100 \mathrm{ml}^{-1}\right)$.

The plant extracts significantly $\left(\chi^{2}=9.2, \mathrm{df}=4, \mathrm{p}<0.05\right)$ reduced the protein content in the larval body and the reduction rate varied from 5.6 to $17.6 \%$ (Figure 1). Among the treatments, neem and joba revealed the highest and lowest reduction, respectively. 


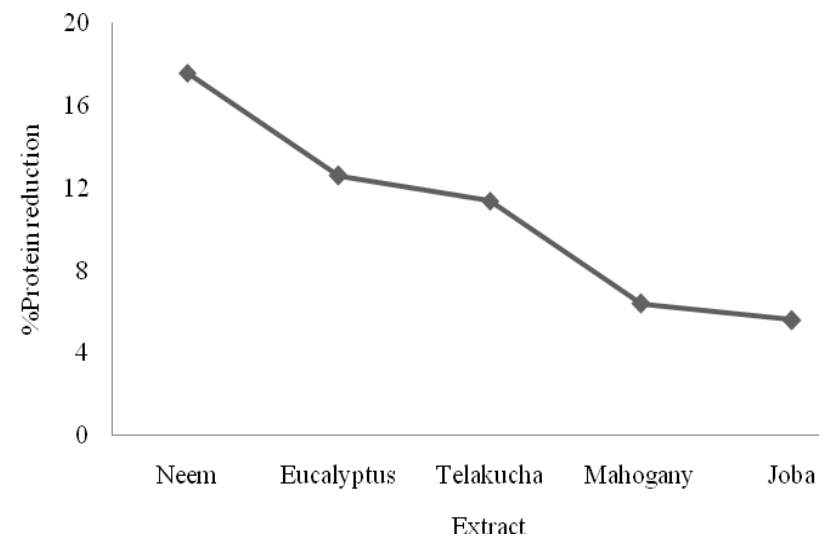

Figure 1. Effect of plant extracts on the protein reduction in Bactrocera cucurbitae larvae reared on ash gourd. $\chi 2_{(4)}=9.2, p<0.05$.

The pupation reduction rate among the treatments ranged from $30.0 \pm 6.2$ to $53.3 \pm$ $3.3 \%$ (Figure 2$)$ and the results differed significantly $\left(\mathrm{F}_{4,20}=3.2, \mathrm{p}<0.05\right)$. The highest and lowest pupation rates were found in neem and joba, respectively. The plant extracts significantly $\left(\mathrm{F}_{4}, 20=3.7, \mathrm{p}<0.05\right)$ reduced the adult emergence and the results varied from $1.9 \pm 0.8$ to $5.0 \pm 0.8 \%$ (Figure 3 ). Neem and joba depicted the highest and lowest level of reduction, respectively.

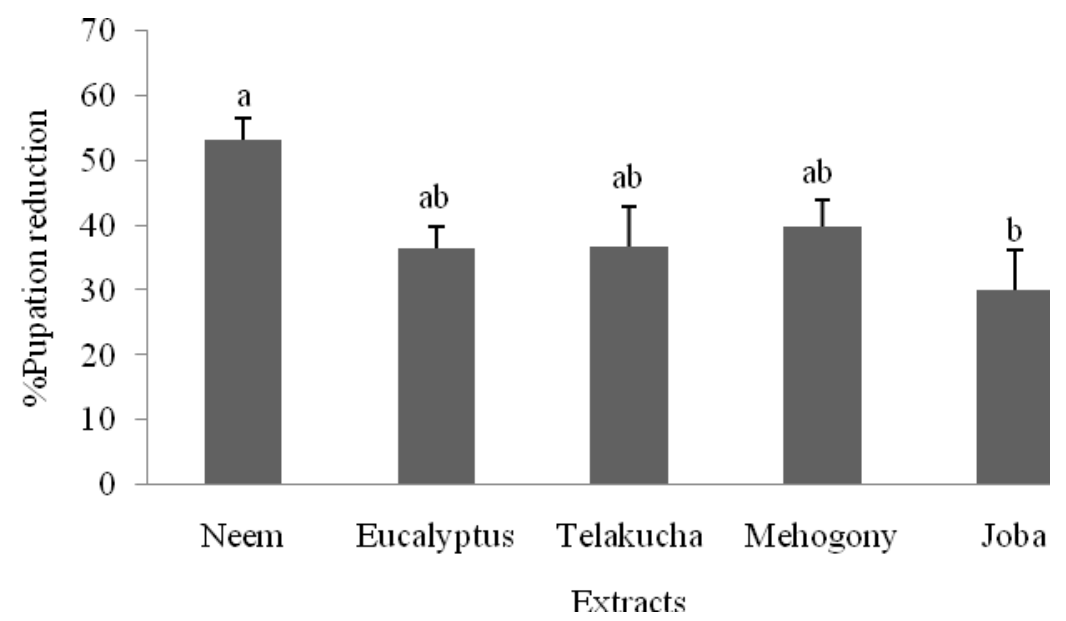

Figure 2. Effect of different plant extracts on the pupation reduction of Bactrocera cucurbitae larvae reared on ash gourd. Data expressed as mean \pm SE. Bars with no common letter(s) are significantly different by Tukey's HSD posthoc statistic at $\mathrm{p} \leq 0.05$. 


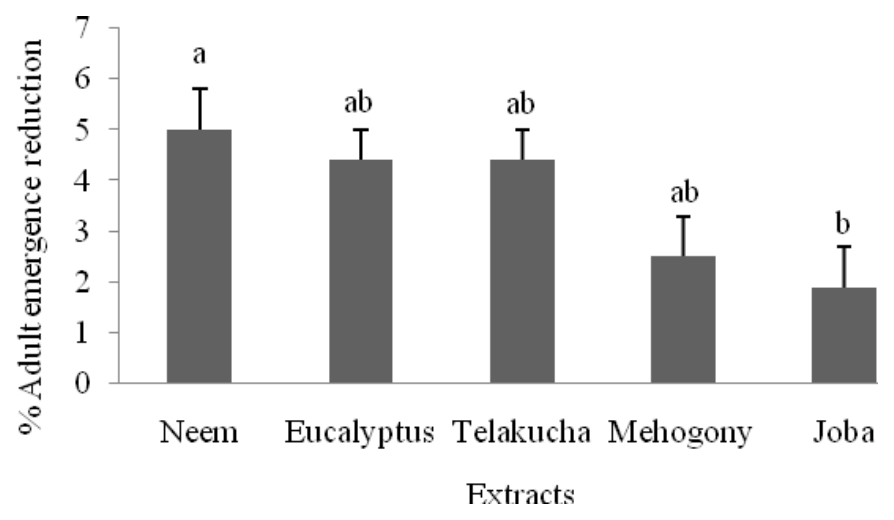

Figure 3. Effect of different plant extracts on the adult emergence reduction of Bactrocera cucurbitae larvae reared on ash gourd. Data expressed as mean \pm SE. Bars with no common letter(s) are significantly different by Tukey's HSD posthoc statistic at $\mathrm{p} \leq 0.05$.

The effect of plant extracts on the body weight reduction of male and female fruit flies are presented in figure 4 . The body weight reduction of male and female flies ranged from $11.0 \pm 0.9$ to $14.6 \pm 0.6 \%$ and $3.8 \pm 0.9$ to $8.2 \pm 0.5 \%$, respectively. Among the treatments, neem depicted the highest level of reduction and the results differed significantly (Male: $\mathrm{F}_{4,20}=4.0, \mathrm{p}<0.05$; Female: $\mathrm{F}_{4,20}=3.1, \mathrm{p}<0.05$ ).

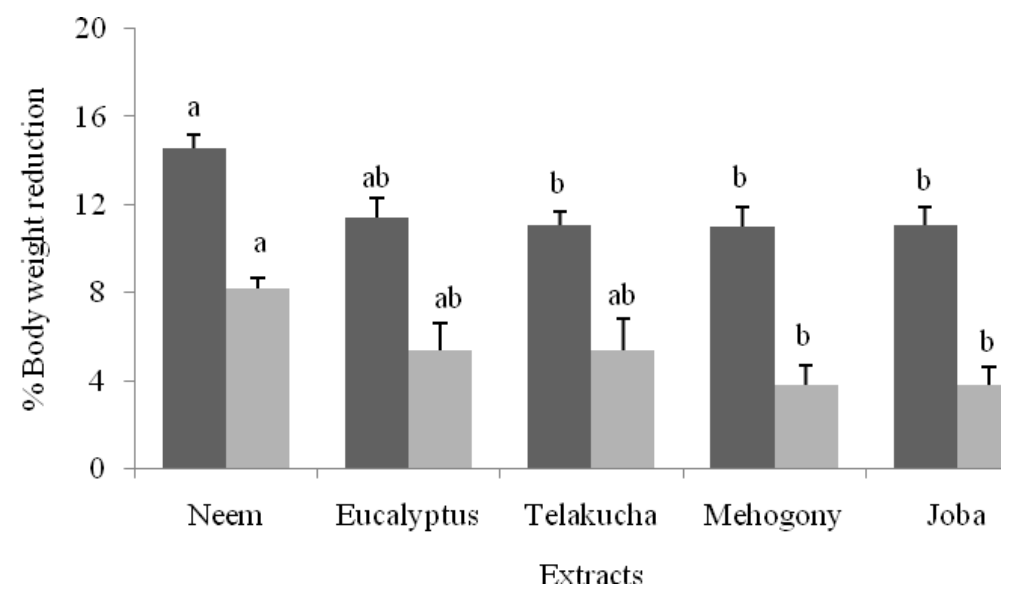

Figure 4. Effect of different plant extracts on the body weight of adult male ( $\square$ ) and female $(\square)$ fruit flies reared on ash gourd. Data expressed as mean \pm SE. Bars with no common letter(s) are significantly different by Tukey's HSD posthoc statistic at $\mathrm{p} \leq 0.05$. 


\section{DISCUSSION}

Plants are sources of different alkaloids such as azadirachtin, azdirol, cymarin, digitoxin, kulactone, limocinin, salanin, toosendanin, xanthotoxin etc which are soluble in water and toxic to herbivore insects. Many authors reported that the aqueous extract of plants has significant effect on insect mortality, their growth and reproduction (Ciepielewska et al., 2005; Roy et al., 2005; Roy et al., 2010; Roy et al., 2012; Ahad et al., 2015; Ahad et al., 2016). There is report that $4 \%$ aqueous extract of neem, akanda and biskatali leaves had significant toxicity effect on lesser grain borer and rice weevil (Amin et al., 2000; Shahjahan and Amin, 2000).

In the present study, all the extracts showed mortality effect on the fruit fly maggot and the results varied with plant species, extract concentrations and exposure periods. This might be the cause that the ingredients of the plants dissolved in water in varied levels and time and those have the ability to dysfunction the nutritional balance of the larvae, thus caused mortality. Fouad et al. (2014) reported that the plant extracts possess broad spectrum toxic substances that interrupt insect's normal physiology and influence on their feeding and mortality.

The tested plant extracts exhibited significant reduction of protein content in larval body, and body weight of adult male and female flies. The extracts might have retarded the maggots from food consumption and efficiency of the conversion of digested food thus reduced the protein content and body weight. Gnanamani and Dhanasekaran (2014) observed 45.4, 13.5, 45.0, 36.9 and 33.1\% protein depletion in the haemolymph of the castor hairy caterpillar Pericallia ricini larvae when they were treated with Catharanthus roseus, Datura metel, Delonix regia, Eucalyptus globulus and Pongamia glabra plant extracts, respectively.

The present findings showed that the plant extracts significantly reduced the pupation and adult emergence of fruit fly. The alkaloid substances of the plants dissolved in water might have acted on the neuroendocrine system of the maggots and interrupted their normal processes of molting and metamorphosis, thus they retained as malformed larvae or pupae. Whatever, the larvae turned into pupae and then adults, most of them exhibited deformations of the wings or other parts of the body. This finding is in accordance with Martinez (2011) who reported that the neem compound azadirachtin and its derivatives typically cause growth inhibition and changes in the metamorphosis of insects. Roy et al. (2014) reported that the leaf extracts of common cocklebur Xanthium strumarium retarded adult emergence of the pulse beetle Callosobruchus chinensis.

The antifeedant, larvicidal and growth inhibition activities of insecticides, controlling the pests at the early stage before they can disperse on the plant would be more preferable in the management of insect pests. In the present study, all the plant extracts retarded growth and development of fruit fly larvae as well as shown their mortality. However, neem and eucalyptus showed potential effect in comparison to other extracts. 
The findings are important baseline information for the potential use of neem and eucalyptus leaf extracts as promising and safe insecticidal agent against $B$. cucurbitae. These plant extracts could be incorporated into the integrated management programs of fruit fly in ash gourd field, which could reduce control costs and environmental adverse effects associated with the use of broad spectrum insecticides.

\section{REFERENCES}

Ahad, M.A., Nahar, M.K., Amin, M.R., Suh, S.J., and Kwon, Y.J. (2015). Biological activities of five weed extracts against Callosobruchus chinensis L. (Coleoptera: Bruchidae). Korean Journal of Applied Entomology, 54, 83-89.

Ahad, M.A., Nahar, M.K., Amin, M.R., Suh, S.J., and Kwon, Y.J. (2016). Effect of weed extracts against pulse beetle, Callosobruchus chinensis L. (Coleoptera: Bruchidae) of mung bean. Bangladesh Journal of Agricultural Research, 41, 75-84.

Amin, M.R., Ara, R., Mukherjee, S., Bhuyain, M.M.H., and Uddin, M.N. (2008). Economic evaluation of different management practices of cucurbit fruit fly (Bactocera cucurbitae) in sweet gourd. Journal of Science and Technology, 6,109-113.

Amin, M.R., Sarkar, C., and Chun, I.J. (2011). Comparison of host plants infestation level and life history of fruit fly (Bactrocera cucurbitae Coquillett) on cucurbitaceous crops. Horticulture, Environment, and Biotechnology, 52, 541-545.

Amin, M.R., Shahjahan, M., Eltaj ,H.F., Iqbal, T.M.T., and Hossain, M.A. (2000). Use of akanda, biskatali and neem as botanical insecticides against lesser grain borer. Bangladesh Journal of Entomology, 10, 1-13.

Atwal, A.S., and Dhaliwal, G.S. (2000). Agricultural Pests of South Asia and Their Management. Kalyani Publication. New Delhi-110002, p. 277-278.

Azad, H.M.S., Amin, M.R., Tithi, D.A., and Hossain, S.M.A. (2011). Performances of three cotton varieties cultivated under economic threshold level based insecticide sprayed and non-sprayed conditions. Our Nature, 9, 21-25.

Ciepielewska, D., Kordan, B., and Nietupski, M. (2005). Effect of plant extracts on some stored-product insect pests. Polish Journal of Natural Sciences, 18, 7-14.

Desneux, N., Decourtye, A., and Delpuech, J.M. (2007). The sublethal effects of pesticides on beneficial arthropods. Annual Review of Entomology, 52, 81-106.

Fouad, H.A., Faroni, L.R.D.A., Tavares, W.S., Ribeiro, R.C., Freitas, S.S., and Zanuncio, J. S.(2014). Botanical extracts of plants from the Brazilian cerrado for the integrated management of Sitotroga cerealella (Lepidoptera: Gelechiidae) in stored grain. Journal of Stored Product Research, 57, 6-11.

Gnanamani, R., and Dhanasekaran, S. (2014). Impact of plant extracts on total free amino acids alterations in the haemolymph of Pericallia ricini. Journal of Entomology and Zoology Studies, 2, 62-67.

Govindachari, T.R., Suresh, G., Geetha, Gopalakrishnan., and Wesly, S.D. (2004). Insect antifeedant and growth regulating activity of neem seed oil- the role of major tetranotriterpenoids. Journal of Applied Entomology, 124, 287-291. 
Kim, S.I., Park, C., Ohh, M.H., Cho, H.C., and Ahn, Y.J. (2003). Contact and fumigant activities of aromatic plant extracts and essential oils against Lasioderma serricorne (Coleoptera: Anobiidae). Journal of Stored Product Research, 39, 11-19.

Mannan, M.A. (2004). Study on the relative preference of fruit fly (Bactrocera cucurbitae) on different cucurbit. Annual Research Report (2004-05), Division of Entomology, BARI, Gazipur. p. 54.

Martinez, S.S. (2011). O nim, Azadiractina indica-natureza, usosmúltiplos, produção. IAPAR, Londrina, p. 205.

Moulton, J.K., Pepper, D.A., and Dennehy, T.J. (2000). Beet armyworm (Spodoptera exigua) resistance to spinosad. Pest Management Science, 56, 842-848.

Mukherjee, S., Tithi, D.A., Bachchu, A.A., Ara, R., and Amin, M.R. (2007). Life history and management of cucurbit fruit fly Bactrocera cucurbitae on sweet gourd. Journal of Science and Technology (Dinajpur), 5, 14-24.

Osoria, A., Martinez, A.M., Schneider, M.I., Diaz, O., Corrales, J.L., Aviles, M.C. (2008). Monitoring of beet armyworm resistance to spinosad and methoxyfenozide in Mexico. Pest Management Science, 64, 1001-1007.

Pineda, S., Martínez, A.M., Figueroa, J.I., Schneider, M.I., Estal, P.D., Viñuela, E., Gómez, B., Smagghe, G., and Budia, F.(2009). Influence of azadirachtin and Methoxyfenozide on Life Parameters of Spodoptera littoralis (Lepidoptera: Noctuidae). Journal of Economic Entomology, 102, 1490-1496.

Rabindranath, K., and Pillai, K.S. (1986). Control of fruit fly of bitter gourd using synthetic pyrethroids. Entomology, 11, 269-272.

Ramada, M., and Messing, R.H. (2003). A survey for potential biocontrol agents of Bactrocera cucurbitae (Diptera: Tephritidae) in Thailand. Proceedings of the Hawaiian Entomological Society, 36,115-122.

Roy, B., Amin, M.R., Jalal, S., and Sarker, B.C. (2012). Bioefficacy of blood leaf plant extracts again pulse beetle, Callosobruchus chinensis (Coleoptera: Bruchidae). Bangladesh Journal of Entomology, 22, 69-77.

Roy, B., Amin, M.R., Jalal, S., Kwon, Y.J., and Suh, S.J. (2014). Evaluation of common cocklebur Xanthium strumarium leaf extract as post-harvest grain protectant of black gram against pulse beetle Callosobruchus chinensis (Coleoptera: Bruchidae) and isolation of crude compound. Entomological Research, 44, 254-261.

Roy, B., Amin, M.R., Uddin, M.N., Islam, A.T.M.S., Islam, M.J., and Halder, B.C. (2005). Leaf extracts of shiyalmutra (Blumea lacera) against lesser grain borer and rice weevil. Journal of Biological Sciences, 5, 201-204.

Roy, B., Jalal, S., Sarker, B.C., Amin, M.R., Jeon, Y.H. and Chun, I.J. (2012). Evaluation of insecticidal activities of common cocklebur fruit extract against pulse beetle Callosobruchus chinensis (Coleoptera: Bruchidae). Korean Journal of Applied Entomology, 51, 325-329.

Roy, B., Sarker, B.C., Amin, M.R., Roy, B.C., and Jalal, S. (2010).Bioefficacy of shiyalmutra leaf extract again rice weevil. Journal of Science and Technology, 8, 1-5. 
Sapkota, R., Dahal, K.C., and Thapa, R.B. (2010). Damage assessment and management of cucurbit fruit flies in spring-summer squash. Journal of Entomology and Nematology, 2, 7-12.

Shahjahan, M., and Amin, M.R. (2000). Evaluation of some plant extracts against rice weevil, Sitophilus oryzae L. Journal of the Asiatic Society of Bangladesh, 26, 213-222.

Ulrichs, C., Mewis, I., Adhikary, S., Bhattacharyya, A., and Goswami, A. (2008). Antifeedant activity and toxicity of leaf extracts from Porteresia coarctata Takeoka and their effects on the physiology of Spodoptera litura F.). Journal of Pest Science, 81, 79-84. 